\title{
Correction to: To See or NOsee: The Debate on the Nocebo Effect and Optimizing the Use of Biosimilars
}

\author{
Mourad F. Rezk • Burkhard Pieper
}

Published online: August 10, 2018

(C) The Author(s) 2018

Correction to: Adv Ther (2018) 35:749-753

https://doi.org/10.1007/s12325-018-0719-8

The article "To See or NOsee: The Debate on the Nocebo Effect and Optimizing the Use of Biosimilars", written by Mourad F. Rezk and Burkhard Pieper was originally published electronically on the publisher's internet portal (currently SpringerLink) on June 5, 2018 without open access.

The copyright of the article changed to (C) The Author(s) 2018 and the article is forthwith distributed under the terms of the Creative Commons Attribution-NonCommercial 4.0 International License (http://creativecommons. org/licenses/by-nc/4.0/), which permits any non-commercial use, distribution, and reproduction in any medium, provided you give

appropriate credit to the original author(s) and the source, provide a link to the Creative Commons license, and Indicate if changes were made.

The original article has been corrected.

Open Access. This article is distributed under the terms of the Creative Commons Attribution-NonCommercial 4.0 International License (http://creativecommons.org/licenses/ by-nc/4.0/), which permits any noncommercial use, distribution, and reproduction in any medium, provided you give appropriate credit to the original author(s) and the source, provide a link to the Creative Commons license, and indicate if changes were made.

The original article can be found online at https://doi. org/10.1007/s12325-018-0719-8.

M. F. Rezk $(\bowtie) \cdot$ B. Pieper

Biogen International GmbH, Zug, Switzerland

e-mail: mouradfarouk.rezk@biogen.com 